\title{
Partitiivi laienemine aspektituks objektikäändeks ${ }^{1}$
}

\author{
Mati Hint \\ Eesti keeleteadlane \\ 10152 Tallinn, Narva mnt 25, Tallinna Ülikool
}

Selgelt otsustavate sündmuste vahele jääb alati palju väikseid, aga salakavalalt olulisi.

Madis Hint. Vaade merele (Tartu: Ilmamaa, 2002, lk 41)

\begin{abstract}
Teesid: Artikkel tõstatab probleemi - kuivõrd on eesti süntaksiuurimine valmis tunnustama keelemuutust, mis kõigutab eesti ja teiste läänemeresoome keelte traditsioonilist moodust väljendada grammatilist aspekti (perfektiivus/imperfektiivus) objekti kaudu: täisobjekti käändevormid (genitiiv ja nominatiiv) väljendavad perfektiivset aspekti ning osaobjekti käändevorm (partitiiv) väljendab imperfektiivset aspekti. Seda erisust ei järgita enam järjekindlalt: indoeuroopa keelte mõjul muutub partitiiv üha sagedamini akusatiivi sarnaseks käändeks, milles aspektivastandus on neutraliseeritud.
\end{abstract}

Märksõnad: aspekti väljendamine, keelemuutused, morfosüntaksi tüpoloogia, objekti kasutusreeglid, partitiivi üldistumine

\section{Sissejuhatav kokkuvõte}

Läänemeresoome keelte osa- ja täisobjekti käsitlevaid süvateoreetilisi uurimusi on prominentsetelt eesti ja soome keeleteadlastelt ning ka rahvusvahelises keeleteaduses ilmunud väikese raamatukogu jagu. Üldiselt keskenduvad nad lõviosas osa- ja täisobjekti kasutamise kirjeldamisele ja reeglistamisele, reeglite täpsustamisele ja semantilisele interpreteerimisele.

Osa- ja täisobjekti semantikas on kesksel kohal lause grammatiline aspekt: kuidas objekti käändevormist (mille võimalused määrab öeldisverbi ja objektnoomeni semantika, osalt ka öeldisverbi grammatiline vorm ja lausetüüp) sõltub lauses väljendatud tegevuse tõlgendamine perfektiivse $v s$. imperfektiivsena, 
teistsuguses terminoloogias resultatiivse $v s$. irresultatiivsena, kooligrammatika lihtsamas terminoloogias lõpetatud-lõpetatava või lõpetamatuna.

Indoeuroopa keelte taustal on läänemeresoome keeltes aspekti väljendamine väga omapärane. Selle omapära haavatavus on kuni kõige viimase ajani saanud suhteliselt vähe tähelepanu, kuigi ebamäärase halli tsooni olemasolu ja kahemõttelised olukorrad objekti vormi valimisel on leidnud käsitlemist (nt Metslang 2001; Erelt 2013: 71-90; päris hiljuti Ogren 2017). Kuid ka sellistes käsitlustes keskendutakse enamasti objektireeglite ja verbiliigituste aina uutele ja terminoloogiliselt keerulisematele täpsustustele ja lihvimistele, justkui tahtmata tunnistada, et olukord on muutumas. Muutuv olukord sarnaneb praegu hiiliva revolutsiooni situatsiooniga: seadusandjad istuvad oma kabinettides ja lihvivad Ancien Régime’i seadusekoodeksit, märkamata või tunnistamata, et selle koodeksi võim on juba löönud kõikuma, et rahvas on hülgamas oma senise identiteedi traditsioone, asendades need lihtsustustega või võõrastelt üle võetud uute kommetega.

Kahtlemata on eesti (ka soome, liivi jt läänemeresoome keelte) objektireeglite (reeglipärasuste) adekvaatne kirjeldamine suur iseväärtus, ka siis, kui see keelenähtus on määratud kaduma või ähmastuma, nii nagu see on kõige drastilisemalt juhtunud salatsiliivis. Aspekti väljendamine objekti käändevormide erisuse abil on reljeefne tüpoloogiline eripära ning keele morfosüntaksi tüpoloogia muutumine tähendab keelelise identiteedi muutumist. Kõik, mis sellise muutuseni viib, väärib tähelepanu, registreerimist ja arutlemist.

Käesoleva kirjutise eesmärgiks ei ole esitada järjekordseid täpsustusi eesti keele osa- ja täisobjekti käänete - osaobjekti puhul ainsuse ja mitmuse partitiivi ning täisobjekti puhul ainsuse genitiivi ning ainsuse ja mitmuse nominatiivi - kasutamisel. Ka ei ole eesmärgiks ülevaade sellekohasest kirjandusest või sellekohase kirjanduse kriitika - see ei olekski ühes artiklis ega isegi monograafias materjali ulatuse tõttu võimalik ega ole selle artikli teema seisukohalt ka vajalik, sest eesmärgiks on teadvustada eesti keele morfosüntaksi tüpoloogia muutumine, mille tendentsiks on partitiivi üldistumine objekti käändena (akusatiivina). Paljud reeglivastased partitiivid on seni kehtinud aspekti väljendamise reeglipärasuste suhtes keelevead, aga selline hinnang ei päästa traditsioonilist keeleidentiteeti ega suuda muutust tagasi hoida või tagasi pöörata. Keeleajalugu õpetab, et iga massiliselt leviv viga võib saada normiks. Õppetunni selles suhtes annavad salatsiliivi keele materjalid (Winkler \& Pajusalu 2016; Hint 2018), väliseestlaste kolmanda põlvkonna objektikasutus ja Eesti ühiskonnas mitte-eestikeelsete kaasmaalaste objektikasutus, mis kõik mõjutavad juba ka kodueestlaste keelt.

Kuidas eesti grammatikakirjanduses kujunesid välja adekvaatsed objektireeglid ja nende seostamine aspekti väljendamisega, seda näitavad valitud 
viited tänapäevastele ja varasematele autoritele-klassikutele. Missuguseid mõttekäike arendatakse objekti käänete ja aspekti väljendamise kohta praegu, seda näitavad valitud viited hiljutistele kirjutistele. Kirjanduse refereeringud on teema jälgimiseks, paljud vägagi olulised autorid jäävad paratamatult viitamata.

\section{Valik viiteid objekti ja aspekti defineerimisele}

Täis- ja osaobjekti kasutamise reeglite ja reeglipärasuste üldtunnustatud ja põhilises vaidlustamisele mittekuuluvat seisu tänapäevase uurituse tasemel väljendavad akadeemiliseks nimetatav "Eesti keele grammatika. II. Süntaks. Lisa: kiri” (Tallinn: Eesti Teaduste Akadeemia Eesti Keele Instituut, 1993; edaspidi EKG II) ja Mati Erelti monograafia “Eesti keele lauseõpetus. Sissejuhatus. Öeldis" (Tartu: Tartu Ülikool, 2013).

Sellisel tasemel sisulise analüüsini on jõutud pika uurimisloo kestel. Selles ajaloos on erinevaid fookuseasetusi: täis- ja osaobjekti kasutamist on reeglistatud lähtudes lause sisust, objektnoomeni semantikast või sõnaliikidest (kvantorfraasid, pronoomenid), öeldisverbi grammatilistest vormidest ning verbisemantikast. Miski nendes nendingutes pole põhimõtteliselt vale, pigem on tegemist olnud piisamatusega - uute lähtekohtade otsimine on vajalik olnud nähtuse keerukuse tõttu. Pilt aspekti väljendamisest täis- ja osaobjekti vormi abil on muutunud sammhaaval mitmetahulisemaks.

Eesti keele keskkooliõpikutes (näiteks Eduard Vääri. Eesti keele õpik keskkoolile. 8., parandatud trükk. Tallinn: Valgus, 1978, lk 117-120) oli kuni 1980. aastateni tavaks anda objektireeglid viidates öeldisverbi grammatilisele vormile (jaatavale/eitavale kõnele, isikulisele/umbisikulisele tegumoele, kõneviisile, $m a$ - ja $d a$-tegevusnimega lausetele). Täissihitise kasutamiseks peab olema täidetud grammatiliste ja semantiliste tunnuste komplekt - jaatavas lauses väljendatakse lõpule viidud või viidavat tegevust ning sihitisnoomen väljendab kõiki viidatavaid esemeid või tervikut (Ostsin kauplusest l e iv a.). Osasihitist kasutatakse, kui lause on eitav, sihitisnoomen väljendab osa, tegevus pole lõpetatud või kordub (Poisid ei ehitanud mu de l l e n n u k it. Ostsin kauplusest le i ba.).

Aspektist otseselt ei räägita, see pole kooligrammatika kategooria või on seda ainult niipalju, kuivõrd kõneldakse (aspekti nimepidi nimetamata) lauses väljendatud tegevuse lõpetatusest või lõpetamatusest. Verbide liigitamine nende semantika järgi jääb ptiikirjas märkusse. Tegevuse lõpuleviimise väljendamine sõnadega ära, läbi, valmis, maha, kinni jääb samuti mõnerealise märkuse tasandile (Ootasin sõ bra siiski ära.). 
Teoreetilised objektikäsitlused muutusid vajalikuks, kui hakati ette valmistama teaduslikuks nimetatavat eesti keele grammatikat. EKG II ettevalmistamise ajal ilmus eesti süntaksi uurijatelt sari grammatika üksikküsimusi käsitlevaid preprinte, sealhulgas ka objekti kohta. Henno Rajandi ja Helle Metslangi lingvistilises essees "Määramata ja määratud objekt" (Tallinn: Valgus, 1979) tuuakse objekti käändevormi valikut kirjeldades arutlusse mõnevõrra laiem semantiliste tunnuste ring, kui oli tavaks-traditsiooniks olnud kooligrammatikates, näiteks võetakse arvesse suhtlussituatsiooni - kas objektnoomen viitab suhtluses varem mainitut või teadaolevat ning kas verbi aspekt on imperfektiivne (osaobjekt partitiivis: Kristjan kirjutas l u u l e t u s t) või perfektiivne (täisobjekt genitiivis: Kristjan kirjutas l u u l e t u s e). Ka pööravad Rajandi ja Metslang tähelepanu lauseliikmete lauserõhulisele/-rõhutule asendile ning intonatsioonile. Mitte kõik selles essees kõneks võetu ei ole edasistes objekti-aspekti käsitlustes leidnud kinnistamist, kuigi essee leidis tähelepanu, nagu näitab ka Valter Tauli retsensioon “Objektisäännön mutkistamista” (Virittäjä 1981, nr 1, lk 79-83).

Tauli põhjalik retsensioon rõhutab, et täisobjekti tingimusena on õigem defineerida resultatiivsust, mitte perfektiivsust, nagu see oli juba traditsiooniks saanud ja nagu teevad ka Rajandi ja Metslang. Näiteks tuleviku sisuga lauses ei tähista täisobjekt lõppenud tegevust, perfektiivset aspekti, vaid prognoositavat resultatiivsust (Homme ma kirjutan lu u let use). Maitseasjaks võib pidada Tauli ettepanekut defineerida ainult binaarse vastanduse osaobjekt/ täisobjekt markeeritud liikme ehk täisobjekti kasutamise tingimused ja jätta definitsiooniga hõlmamata ala osaobjekti territooriumiks. Täisobjekti käsitamine vastanduse markeeritud liikmena on põhjendatud, sest binaarse opositsiooni neutraliseerumisel (aga sellise tendentsiga objektireeglite lõdvenemise-ähmastumise korral tegemist ongi) jääb varasemast opositsioonipaarist tavaliselt ellu opositsiooni markeerimata (eritunnusteta) liige, objekti puhul niisiis partitiiv osaobjekti käändena. (Trubetzkoy fonoloogiateoorias nimetatakse seda reduktiivseks neutralisatsiooniks, vt Trubetzkoy 1960: 265 jj; grammatiliste opositsioonide neutralisatsioon ei pea olema põhimõtteliselt teistsugune.)

Tauli käsitlusega haakub uuemast objektikirjandusest Pille Esloni ja Katre Õimu artikkel “Objektikäänete kasutamisest sageduse ja markeerituse seisukohalt” (ESUKA - JEFUL 2010, kd 1, nr 2, lk 241-261). Eslon ja Õim sedastavad partitiivi eelisseisundit objektikäändena, kuid nad on optimistlikud selles suhtes, et objektikäänete kasutamise varieeruvuski ei ole ohuks grammatika soomeugrilisusele. Kahjuks näitab liivi keel (ja salatsiliivi keel eriti), et grammatika soomeugrilisuse säilimine ei ole garanteeritud.

EKG II jaotab verbid piirivõimalusega tegevust väljendavateks ja piirivõimaluseta tegevust väljendavateks verbideks - esimestes võib esineda 
nii osa- kui ka täisobjekt (Ma ehitan suvilat/suvila), neid nimetatakse aspektiverbideks, teistes üksnes osaobjekt ( $M a$ alahindasin $P$ e e $t r i t$ ), neid nimetatakse partitiivverbideks ( $\$ 506,1 \mathrm{k} 49-51)$. Täisobjekti puhul on tegevus tulemuslik ehk resultatiivne või lõpetatud ehk perfektiivne: Ta luges ra a mat u läbi. (\$ 507, lk 51).

Uuemas aspekti käsitluses jagab Mati Erelt (Eesti keele lauseõpetus. Sissejuhatus. Öeldis. Tartu, 2013, lk 71-90, eriti lk 71-73) verbid kolmeks:

1) imperfektiivsed verbid, mis jagunevad intransitiivverbideks (nt elama, magama) ja transitiivverbideks (nt vihkama, vaatama); transitiivse imperfektiivse verbi objekt on üldjuhul partitiivis (Jüri armastab M a r e t.); 2) perfektiivsed verbid, mis on enamasti intransitiivsed (nt lahkuma, uinuma); kui perfektiivne verb on transitiivne, siis on tal jaatavas lauses alati täissihitis (Jüri saavutas e e $s$ m ärg $i$.);

3) imperfektiiv-perfektiivsed ehk aspektiverbid on valdavalt transitiivsed (ehitama, kirjutama), nad väljendavad aspekti objekti käände abil - täissihitisena omastavas ja nimetavas (Jüri tõi Marele to r di. Mehed ehitasid endale s u vi l a d.), osasihitisena osastavas käändes (Jüri tõi Marele to r t $i$.).

See on objekti-aspekti reeglipärade viimistletud kokkuvõte. Ka teistel süntaksiuurijatel (nt Helle Metslang) leidub sama detailseid, kuid teisiti üles ehitatud objekti-aspekti käsitlusi. Mitme tänapäevase süntaksiuurija puhul paneb hämmastama eesti täis- ja osaobjekti kõige väärikamatest esmakäsitlejatest möödavaatmine: Erelti eelnevas viidatud monograafia (preprindi) kirjanduse loetelus (33 lk!) puudub Eduard Ahrens, kes esimesena (1853. aastal) esitas täis- ja osaobjekti kasutamise reeglid-reeglipärasused, mille põhimõtted (üksikvigadest mööda vaadates) on adekvaatsed ka tänapäeva seisukohalt ja põhimõtete poolest üsna sarnased Mati Erelti ja EKG II objekti-aspekti kirjeldustele (EKG II ei viita ei Ahrensit ega Wiedemanni).

Selle artikli trükiks viimistlemise ajal ilmus Tartu Ülikooli kirjastusel Mati Erelti ja Helle Metslangi toimetatud “Eesti keele süntaks" (Eesti keele varamu III. Tartu, 2017), mis "toob lugeja ette kõigi aegade ulatuslikema ülevaate eesti keele lauseehituse kohta” (lk 5) ning esitab ka konspektiivse hinnangu Eduard Ahrensi ja Ferdinand Johann Wiedemanni grammatikate kohta (lk 31-32). Mati Erelti aspekti käsitlus selles suurteoses (lk 112-128) järgib oluliselt sama autori varasemat täppistööd (Erelt 2013) ja ka Helle Metslangi kirjutatud sihitise ülevaade (lk 258-277) toetub varasematele süvauurimustele; varasemast selgemalt on eritletud sihitisekäändelisi määrusi (lk 275-277). Helle Metslangi kvantorfraasi esitlus (lk 463-478) märgib küll kvantori ühildumistendentsi, kuid põhiliselt juhtudel, mis on keeles juba kinnistunud: enamikud inimesed, enamikele inimestele, osadele inimestele (lk 471). Käesoleva 
artikli seisukoht on, et kvantorfraasides on traditsiooniliseks peetavate mallide lagunemise tendents ammu tugevam, kui deskriptiivsed-normatiivsed reeglid möönavad (nt tüüp kolm esimest sekundit $\Rightarrow$ esimesed kolm sekundit).

19. sajandi esimese poole lõpuni andsid eestikeelses kirjasõnas tooni baltisaksa autorid-estofiilid, kes eriti ei hoolinud nende keeleloogikale arusaamatutest objekti vormi kaudu aspekti väljendamise moodustest eesti keeles. Selle kohta tolleaegses kirjasõnas (jumalasõna kaasa arvatud) näiteid leida pole raske. See võõrmõjudele ehitatud traditsioon mõjutas ka eesti autoreid veel aastakümneid pärast Ahrensi grammatika ilmumist (Lydia Koidula: "kel s ü d a nt andnud ma", "ema kombel kinni kata lapse tuksvat rind a sa"), täpsemateks hinnanguteks on vaja tolleaegse eestikeelse kirjasõna korpuse analüüsi. Ent suur plaan on selge selletagi.

Esimese tänapäevasele lähedase täis- ja osaobjekti kasutamise kirjelduse esitas Eduard Ahrens oma "Grammatik der Ehstnischen Sprache Revalschen Dialektes” 2. trükis (Reval, 1853). Nüüd on see grammatika ja mõni teinegi Ahrensi eesti keele alane töö kättesaadav ka eestikeelses tõlkes juubeliväljaandes "Uue ajastu misjonilingvist. Eduard Ahrens 200" (koostanud ja toimetanud Kristiina Ross. Tallinn: Eesti Keele Sihtasutus, 2003; järgnevas viidatakse selle väljaande lehekülgi, grammatiline terminoloogia on tänapäevastatud).

Määramata objekti väljendatakse partitiiviga, määratud objekti imperatiivi ja umbisikulise tegumoe korral nominatiiviga, kõikide muude verbivormide korral ainsuses genitiiviga ning mitmuses nominatiiviga (\$ 260, lk 327: Jumal andis tänawu pöuda; Jumal on sulle ter $w$ ed $k \ddot{a} e d$ ja jalad annud ja weel pealegi möistuse).

$\S 248$. Esimene põhiseadus: objekt on määratud, kui see väljendab tervikut, ja määramata, kui see märgib vaid ühte osa. Nt wöttis le $i b a$; wöttis le iw a laualt.

$\S 249$. Objekti kaasuse valik ei olene nimelt mitte ainult objektist enesest, vaid ka verbist. Verbki on kas määratud või määramata.

Teine põhiseadus: määramata verb nõuab alati määramata objekti, määratud verb nõuab aga ainult siis määratud objekti, kui see väljendab tervikut. Kui objekt märgib ühte osa, siis verb teda ei mõjuta. Verb on määramata, kui ta väljendab tegevust, mis veel kestab või mis on lakanud ilmselge lõpetamiseta; verb on määratud, kui tegevus lakkab selge lõpetamisega või on lõpetatud.

$\S 250$. Mõned verbid on oma olemuselt määramata ja nõuavad seetõttu alati määramata objekti. Nendeks verbideks on: 1) niisugused, mis väljendavad meelelist või hingelist tajumist (nägema, kuulma, .. kartma, himustama ..); 2) niisugused, mis väljendavad meele või hinge mõjutamist (kiitma, laitma, önnistama ..); 3) veel järgmised: oskama, uskuma .. Nt karda J u ma lat; önnistas oma la p si; uskus tema lu ba mi si .. 
§ 251. Kõik teised verbid võivad esineda nii määramata kui ka määratud kujul. Viimasel juhul osutab tegevuse lõpetatusele enamasti mingi lisandus (adverb, noomen või verb), nt ajas hob u se tanuwast välja, löi ho b u se veriseks, ho b u ne aeti ära, ma löpetasin k a ng g a ära; öpetas temale r a a m a tu selgeks, lubas küll jo o mis e maha jätta, pane a hi küdema .. (näited $§ 251$, lk $317 \mathrm{jm})$.

Ahrensi objektikäsitlus mõjub tänapäevasena, sest ta läheb tervik-osa vastandusest palju sügavamale, kaasates aspekti (seda sõna kasutamata) defineerimisse verbi semantika.

Ahrensi objektikäsitlus ei ole vigadeta (vt nt § 263, lk 329), kuid on siiski väga põhjalik: ta märkas isegi imperatiivi 3. isiku erinevust 2. isikust (vt § 265, lk 331), kuigi ei teinud sellest järjekindlalt adekvaatseid järeldusi: Jumal andku selle patu andeks (pro Jumal andku see patt andeks). Need eksimused on tühiasi, võrreldes tema revolutsiooniliste uuendustega eesti kirjakeele ja eesti kirikukeele objektikäsitluses. Nagu öeldud, on Ahrensi objektikäsitlused lähedal sellele, kuidas objekti-aspekti käsitletakse tänapäeval. Ahrensi tõeallikateks olid võõraste eeskujude järgi konstrueeritud kirikukeele asemel rahvakeel ja soome keele grammatika ülesehitus.

"Uue ajastu misjonilingvist. Eduard Ahrens 200" sisaldab ka eestlastele jutlustavatele Ahrensi ametivendadele mõeldud keelelise abivahendi "Eesti Piibli keelevead" (Sprachfehler der Ehstnischen Bibel. Reval, 1853). Juubeliväljaandes hõlmab piibli 1835. aasta trüki objektivigade loend paarkümmend lehekülge (lk 467-485). Kuigi Ahrensi loendis leidub ka vaieldavaid ja koguni vigaseid näiteid, algab selge arusaamine täis- ja osaobjekti kasutamisest Ahrensi grammatikast ja piibli objektivigade loendist. Ahrensini oli piiblis osaobjekti ja täisobjekti kasutatud segiläbi: Algmisses loi Jummal t a e w a st ja m a a d - 1. Moosese 1:1; Ja nemmad kuulsid Jehowa Jummala he a le 1. Moosese 3:8 (Piibli Ramat 1739).

Ahrensi võitlus objekti õigete käändevormide kasutamise eest oli murranguline (vt Kristiina Ross. Viimane misjonilingvist Eduard Ahrens eesti kirjakeele reformijana. Keel ja Kirjandus 2003, nr 5, lk 321-330; Kristiina Ross. Eduard Ahrens 200. Oma Keel 2003, nr 2, lk 53-59). Ahrensita oleks alles kujunevat eesti kirjakeelt võinud ähvardada rahvakeelest võõrdumine.

Ferdinand Johann Wiedemann (Grammatik der Ehstnischen Sprache. St.-Pétersbourg, 1875. Faksiimiletrükk: Grammatik der Estnischen Sprache. Tallinn: Eesti Keele Sihtasutus, 2005; tõlge eesti keelde: Eesti keele grammatika. Tõlkinud Heli Laanekask. Tallinn: Eesti Teaduste Akadeemia Emakeele Selts, 2011; järgnevas viidatakse saksakeelset originaali) hindab oma grammatika sissejuhatuses Ahrensit väga kõrgelt ka sellest seisukohast, 
et Ahrensil jätkus enesekindlust mitte lasta end eesti keele kirjeldamisel mõjutada senisest traditsioonist, mille osaks oli ka saksa ja ladina keele eeskujudest lähtumine; Ahrens toetus põhjaeesti rahvakeelele ja soome keele grammatikate eeskujule (lk 17-18).

Wiedemanni objektikäsitlus ( $§ 194-201$, lk 620-640) lähtub ilmselgelt Ahrensist. Kõigepealt liigitab ka Wiedemann objekti määratud (bestimmte) ja määramatuks (unbestimmte); tal on koguni näitelauseid, mis on Ahrensilt üle võetud (ta peksis la st, peksis l a p s e vigaseks jt; vt lk 632; vrd Ahrens 2003: $\S 251$, lk 317). Nagu Ahrens, nii kasutab ka Wiedemann objekti vormi valikut reeglistades viiteid öeldise grammatilisele vormile ja lauseehitusele (eitav lause / jaatav lause, objektiga seostatud infinitiivid ja verbaalnoomenid), sõnaliikidele (pronoomenid, numeraalid), lõpetamata ja lõpetatud (resultatiivsele) tegevusele ning adverbidele ( $\$ 198,1 \mathrm{k}$ 630-632: ma lugesin s e d a r a m a tu m.l. se e rāmatu läbi; sa oled o ma térvize ära jōnud), objektnoomenite tähendusele ning öeldisverbide tähendusgruppidele (vt ka grammatika sisukorras antud objektiparagrahvide iseloomustusi, lk XVII). Ja lõpuks on ka Wiedemanni objektinäidete hulgas niisuguseid, mida ei saa pidada õigeteks.

Wiedemann juhib oma objektikäsitluse alguses tähelepanu ka sellele, et haritud eestlastel on emakeeleinstinkt oma hariduskeele mõjul nõrgenenud, mistõttu ka eestikeelseid trükitud allikaid ei saa süntaksi kirjeldamisel kuigi tihti usaldusväärseks pidada.

Eesti keele süntaksi adekvaatsusele lähenevad kirjeldused algavad Ahrensist ja Wiedemannist, kusjuures nende objektikäsitlus sarnaneb põhimõtteliselt tänapäevastele vaadetele.

Karl Kondi 1959. aastal kaitstud väitekirja täiendatud trükivariant “Käändsõnaline objekt läänemeresoome keeltes” (Tallinn: Eesti NSV Teaduste Akadeemia Keele ja Kirjanduse Instituut, 1963) kuulub läänemeresoome keelte objekti-aspekti uurimuste klassikasse. Näitematerjal teistest läänemeresoome keeltest loob raami selle mõistmiseks, miks ka eesti keeles on resultatiivsuse väljendamiseks täisobjekti käändevormile lisaks välja kujundatud täiendavad võimalused, eelkõige perfektiivsed verbipartiklid, nagu ära, välja, maha, kinni, läbi, üle jt (Kont nimetab neid prefiksilaadilisteks adverbiaalideks, lk 93-94).

Keeleajalooliselt on nii, nagu Kont kirjutab: “Objekti käändeline vorm on läänemeresoome keeltes verbi tegevuse irresultatiivsuse ning jätkuvuse või resultatiivsuse ning lõpetatuse peamiseks ja kõige järjekindlamaks väljendusvahendiks, kuna verbi enda vormistik ei võimalda seda esile tuua" (lk 53). Kuid ka Kondi tekstis leiab palju näiteid selle kohta, et olukorrad eri keeltes on muutunud ning objekti käändevorm ei ole mõneski keeles või sõnatüübis 
enam ei kõige järjekindlamaks ega ka piisavaks resultatiivsuse/irresultatiivsuse eristajaks.

Kont toetub oma reeglites-reeglipärades samadele liigitustele, mis kehtivad tänapäevalgi: resultatiivsed ja irresultatiivsed verbid, adverbiaalide osa resultatiivse verbi ja totaalobjekti seoses, öeldisverbi grammatilise vormi mõju objekti käändevormile. Selles viimases väärib tähelepanu eitava lause objekti vorm: see peaks traditsioonilise käsituse järgi olema tingimata partitiiv (osaobjekt). Aga samas toob Kont mitmel leheküljel liivi keelest ning eesti ja soome murretest näiteid, mis ei vasta reeglile, olgu siis seletuseks kasvõi võõrmõjud (lk 114-116).

Tänapäevasest vaatepunktist väärib tähelepanu allpeatükk "Partsiaalobjekti kasutamise laienemine" (lk 97-106) - teema, mis on käesoleva artikli ajendiks. Pool sajandit hiljem on see tendents eesti keeles jõuliselt tugevnemas traditsiooniline resultatiivsuse väljendamine täisobjekti käändevormi (genitiiv või nominatiiv) abil muutub üha ebajärjekindlamaks.

Karl Kondi monograafia väärtuseks on ka väga põhjalik ülevaade varasematest ja Kondi kaasaegsete objektikäsitlustest.

\section{Muutused aspekti väljendamisel: mõned käsitlused}

Viimastel aastatel on ilmunud artikleid, mille ühisnimetajaks on objekti vormi abil aspekti väljendamise probleemid. Järgnevas refereeritakse väikest valikut selliste kirjutiste teemadest.

Helle Metslangi põhjalik artikkel "On the development of the Estonian aspect: The verbal particle ära" (Metslang 2001: lk 443-479) toob esile eesti keele sisesed ja keelevälised mõjud, mis on aspekti väljendamisel teinud vajalikuks perfektiivse tähendusega verbipartiklite (kõige sagedasem ja universaalsem neist ära) kasutamise. Nende põhjuste hulgas on ka häälikumuutustest tingitud grammatiline homonüümia mitmes suures morfoloogilises sõnatüübis (lk 444):

soome keeles: nom, gen, part eristatavad

Lintu rakensi pesää (part; imperfektiivne) $\Rightarrow$

Lintu rakensi pesän (gen; perfektiivne) $\Rightarrow$ eesti keeles: nom, gen, part

homonüümsed

Lind ehitas pesa (aspekt ebaselge)

Lind ehitas pesa (aspekt ebaselge)

Lind ehitas pesa valmis

(perfektiivne) 
Objektikäänete grammatiline homonüümia pesa-tüüpi astmevahelduseta sõnades on üks lisapõhjus, mis soodustab täis- ja osaobjekti piiri ähmastumist.

Metslangi käsitluses on saksa keele verbiprefiksite abil väljendatud aspekt (lk 455) ning vene keele verbivormides väljendatud aspekt (prefiksaalsus kaasa arvatud; vt lk 467) mõjutanud perfektiivsete verbipartiklite, nagu ära, välja, valmis jt, kasutusele tulekut eesti keeles. See on kahtlemata nii. Kokkuvõttes leiab Metslang, et keelesiseste häälikumuutuste ning saksa ja vene keele mõju on muutnud perfektiivsuse ja imperfektiivsuse väljendamist eesti keeles - ilma perfektiivse tähendusega verbipartikliteta ei toimiks aspekti väljendamine järjekindlalt. Kuid ka Metslang ei käsitle oma 2001 ilmunud artiklis seda, mis on käesoleva kirjutise aine: aspekti traditsiooniline väljendamine igapäevaselt käibivas eesti keeles on löönud kõikuma.

Miina Norviku ja Piret Piiroja artiklis "Aeg ja aspekt” (ESUKA - JEFUL 2013, kd 4, nr 1, lk 53-72) rõhutatakse aspekti puhul vastandust perfektiivsus vs. imperfektiivus ning näidatakse aspekti ja aja tihedat seost. Norvik ja Piiroja käsitlevad küll perfektiivsusmarkereid ära, välja, läbi jts, vt näitelause (18) Ma pesen n õ u d ära, kuid autorid ei vihja aspekti väljendamise praegustele muutustele. Näitelause (23) Mari laulis k olm la ulu (perfektiivne aspekt) võib praegu, anno 2017, ka soliidsetes keelekanalites esineda kujul Mari laulis k o l m e la u l u (imperfektiivsuse ja perfektiivsuse vastandus on maha võetud, seda ei väljendata). Traditsioonilises grammatikas poleks viimane lause võimalik või oleks võimalik, kui imperfektiivsus oleks selgesti väljendatud, näiteks Mari laulis parajasti oma k olme la ul u, kui..

Anne Tamm ja Piibi-Kai Kivik jõuavad artiklis “A learner's grammar for Estonian: Insights from typological research” (ESUKA - JEFUL 2017, kd 8, nr 1, lk 263-281) tõdemuseni, mis on käesoleva artikli probleemipüstituse jaoks oluline: vene emakeelega kõnelejad ülekasutavad eesti keeles objekti väljendamisel partitiivi, st imperfektiivset aspekti (lk 268). Eesti keele objektireeglite seisukohalt vigane näitelause (1) Tartu ülikool annab üliõpilasele he ad võ i malust (pro hea võimaluse) ennast igakülgselt arendada vastab Euroopa keelte kõnelejate arusaamisele objektist (lk 270).

Ulatuslik bibliograafia juhib analüüside juurde, mis seletavad eesti objektireegleid ja põhjusi - miks võõrkeelsed eesti keele õppijad eksivad nende reeglite vastu. Et omastava (täisobjekti) ja osastava (osaobjekti) vahel valimine on venekeelsetele probleem, seda on Raili Pool käsitlenud juba 2007. aastal oma väitekirjas (Pool 2007)2 ning Anna Verschik 2011. aastal J. V. Veski päeva ettekandes (Verschik 2011).

See viib käesoleva artikli teema juurde: aspekti väljendamine osa- ja täisobjekti abil on eesti keele praeguses kasutuses kõikuma löönud, ning selle ühe põhjusena võib oletada indoeuroopa keelte üldist kombineeritud mõju, tulgu 
see siis vene või inglise, saksa või rootsi keele poolt. Miks aspekti väljendamine eesti keeles ei lagunenud juba saksa keele ülemvõimu ajal, seda saab seletada suhteliselt vähese saksa keele oskusega maarahva masside hulgas; saksa keel oli eesti haritlaste, aga mitte talupoegade keel. Ja haritlased kasutasidki osaobjekti rohkem kui õigus.

Käesoleva artikli teemapüstitusega Katre Õimu mälestuskonverentsil (17. veebruaril 2017) samal ajal on David Ogren käsitlenud artiklis "Finiitverbi mõju objekti käändele $\boldsymbol{d a}$-infinitiiviga objektikonstruktsioonis” (Keel ja Kirjandus 2017, nr 4, lk 258-271) täis- ja osaobjekti kõikumist ja varieeruvust, siiski selle olulise erinevusega, et Ogren ei kahtlusta objekti vormi abil aspekti väljendamise nõrgenemist, vaid võttes antusena täis- ja osaobjekti valiku tuntud reeglid, lihtsalt nendib osalist ebamäärasust täis- ja osaobjekti valimisel: Ta kardab kaotada oma töökoh $(t) a$; Ogreni enda autoritekstis näiteks ka nii: “Artiklis püütakse leida vast us $(t)$ küsimusele, kuidas mõjutab finiitverb seda laiendavas $d a$-infinitiiviga fraasis esineva objekti käände valikut" (lk 258).

Ogren nendib tegeliku keelekasutuse ebajärjekindlust, mistõttu saab rääkida ainult üldistest tendentsidest ja motivatsioonidest, mitte kindlatest põhjustest, miks ühes või teises lauses on kasutatud üht või teist käänet (lk 263). Et tendentsiks on aspekti väljendamise nõrgenemine sel teel, et objekti käändeks võib üldistuda partitiiv, seda Ogren ei oleta. Ogreni paljude tähelepanekute hulgast on põhjust esile tõsta nähtust, mida võiks nimetada semantiliseks eituseks: "partsiaalobjekti osakaal on omadussõnaga võimatu 94\%, sõnaga võimalik ainult 32\%", st eitusena võidakse käsitada lisaks predikaadis verbi vormiga väljendatud eitusele ka leksikaalselt väljendatud sisulist eitust jaatava predikaadiga lauses. Ogreni näide Selles linnas on võimatu leida h e ad töökohta ja Selles linnas on võimalik leida he a töök oht/he ad töök o h t a (lk 265) tähendab, et kui lause väljendab tõenäolisemat sündmust, siis on totaalobjekt sagedasem (lk 266), kui lause väljendab irresultatiivsust, siis eelistatakse partsiaalobjekti ka jaatava öeldise korral (lk 269).

Ogren annab ka lühikese mitteammendava ülevaate sama teema teiste uurijate olulisematest töödest (Johannes Aavik, Valter Tauli, Mati Erelt, Pille Penjam), kuid palju objektikirjanduse klassikat ja süvauurimusi on ka jäänud viitamata (Karl Kont, Mati Erelti kõige värskemad uurimused, Henno Rajandi ja Helle Metslang, samuti vanemast klassikast Eduard Ahrens ja F. J. Wiedemann).

Ilze Tālberga ja Aive Mandel käsitlevad artiklis "On the imperfective and perfective aspect in Estonian and Latvian” (ESUKA - JEFUL 2017, kd 8, nr 1, lk 241-261) perfektiivse ja imperfektiivse aspekti väljendamise grammatilisi tüüpe eesti ja läti keeles. Läti keeles väljendatakse perfektiivset 
aspekti peamiselt 11 verbiprefiksi abil: $a i z-, a p-, a t-, i e-, i z_{-}, n o_{-}^{-}, p a-, p \overline{a r}-, p i e$, $s a-, u z-$. Prefiksita verbivormid tähendavad üldiselt imperfektiivset aspekti.

Eesti keele aspekti väljendamist kirjeldatakse traditsiooniliselt: imperfektiivset aspekti tähistab osaobjekt partitiivis, perfektiivset aspekti tähistab täisobjekt nominatiivis või genitiivis või täisobjekt + perfektiivsust näitav verbipartikkel (ära, maha, välja, kinni jt).

Kas ka eesti keeles võiksid areneda verbiprefiksid (nagu näiteks tegijanimes ärapanija)? Eesti keel ilmselt ei lähe seda teed, eesti keel võib minna hoopis lihtsamat teed - hakata perfektiivsust-resultatiivsust väljendama perfektiivsete verbipartiklite (ära jt) abil, jättes perfektiivsuse $v s$. imperfektiivsuse eristamise objekti vormi kaudu fakultatiivseks. See küsimus Tālberga ja Mandeli artiklis sellisel kujul ei kerki. Kuid läänemeresoome keelte aspektiloos on rabav tüpoloogilise muutuse näide: liivi keel ja eriti salatsiliivi keel on enne oma hääbumist perfektiivse-resultatiivse aspekti väljendamiseks ülisuurel määral üle võtnud läti verbiprefiksid.

Johann Andreas Sjögreni 1846. aastal kogutud salatsiliivi keele materjalide täielik väljaanne (Winkler \& Pajusalu. Salis-Livisch I: J. A. Sjögrens Manuskript. Wiesbaden: Harrassowitz Verlag, 2016) annab olulise toetuspunkti mõistmaks, kuidas häälikuajaloolised muutused ning indoeuroopa keelte mõju võib erodeerida traditsioonilist läänemeresoomelikku aspekti väljendamist objekti käändevormiga.

Traditsiooniline täis- ja osaobjekti vastandamine toimib veel päris hästi soome keeles, kus nominatiiv, genitiiv ja partitiiv on äratuntavalt erivormilised kõigis sõnatüüpides. Eesti keeles see enam päris nii pole: pesa-vana-tüüpi sõnades on põhjaeestilises kirjakeeles need objektikäänded homonüümsed, õde-tüüpi laadivahelduslikes sõnades on homonüümsed nominatiiv ja partitiiv, maa-tüüpi sõnades on homonüümsed ainsuse nominatiiv ja genitiiv ning ainsuse partitiiv ja mitmuse nominatiiv (nt Ta hoidis oma m a a d lastele - kas partitiivne osaobjekt või mitmuse nominatiivis täisobjekt?). Kuramaa liivi keeles on väga paljudes sõnatüüpides nominatiiv ja genitiiv homonüümsed, nende vormiline eristamine pole võimalik (järjekindlalt on nominatiiv ja genitiiv erinevad pronoomenites ja noomeni sõnatüüpides, mis vastavad eesti keele tugevneva astmevaheldusega sõnatüüpidele - nagu nt võ̃oras - ning ne-s-sõnadele).

19. sajandi teisel poolel hääbunud salatsiliivi keeles on objektikäänete kokkulangevus veelgi ulatuslikum: mitte ainult nominatiiv ja genitiiv, vaid ka partitiiv ja sageli koguni illatiiv on nominatiivi ja genitiiviga homonüümsed (vormiliselt eristamatud) väga paljudes sõnatüüpides, sealhulgas ka sellistes tüüpides, kus eesti keeles hoiab objektikäänded eristatavatena nõrgenev astmevaheldus (laadivaheldus) või kvantitatiivne astmevaheldus (vältevaheldus); nt on salatsiliivis sõnades nurm, paik, posk 'põsk', vel vel' 'vend' nominatiiv, 
genitiiv ja partitiiv homonüümsed. See tähendab, et nimisõnade valdavas osas polegi aspekti väljendamine objekti vormi abil võimalik või on võimalik üksnes siis, kui objektnoomeni ees on asesõna, mille käändevormid ei ole homonüümsed. Üsna ootuspärane on perfektiivsusadverbide kasutamine: sina uod yd (genitiiv) v aj s k jära tappen 'sina oled ühe vasika ära tapnud' (lk 231); eesti keele sarnaselt kasutatakse salatsiliivis perfektiivsusadverbe ka lausetes, kus objekti pole: Täma jeeli jära broutsis mädest (lk 138) 'Ta eile ära sõitis meie juurest'. Kuid mõlemas liivi keeles on aspekti väljendamisel kasutusele võetud läti keele perfektiivsust väljendavad verbiprefiksid: äsjase salatsiliivi näitega samaväärne on Vaj sie Izand om ajzbroutsen? 'Kas see härra on ära sõitnud?' (lk 149).

Läti keeles väljendavad verbiprefiksid perfektiivsust. Salatsiliivi keeles on läti verbiprefiksite kasutamine nii valdav, et verbiprefikseid kasutatakse sealgi, kus läänemeresoomeline keeleloogika ei näe aspekti väljendamise vajadust. Kui tõlgitakse lätikeelne lause salatsiliivisse, siis kasutatakse läti verbiprefikseid liivi verbitüve ees tihti täpselt läti keele mustri järgi: Sujz kaクgtest sa-uulis, ajz-ajlis 'Susi kangesti ulgus, jooksis ära' (lk 329); esimese verbi prefiks ei tundu vajalik, teise verbi prefiks näitab perfektiivsust ('jooksis ära').

Süntaktomorfoloogilise tüpoloogia seisukohalt on perfektiivsuse/resultatiivsuse väljendamise skaala ühes otsas soome keeles säilinud traditsiooniline viis väljendada aspekti objektivormi kaudu, skaala teises otsas on salatsiliivi keel, kus aspekti väljendamiseks on suurel määral üle võetud läti keele verbiprefiksid. Aspekti väljendamine väljaspool verbivormi ei ole muutunud keeleoludes osutunud stabiilseks. Võrdle:

Soome keel:

aspekti väljendab objekti käändevorm, mõnel puhul koos perfektiivsusadverbiga (nt pois).

\section{Eesti kirjakeel:}

aspekti väljendab objekti käändevorm, sageli koos perfektiivsusadverbiga (ära jt).
Liivi keel, eriti salatsiliivi: aspekti väljendamine on läti verbiprefiksite näol suurel määral üle kantud verbile.

\section{Eberhard Winkler väidab käsitluses "Verbiprefiksid Salatsi liivi keeles"} (ESUKA - JEFUL 2017, kd 8, nr 1, lk 349-357), et läti “verbiprefiksid on Salatsi liivis omaks võetud, kuid seda ainult vähesel määral” (lk 349). Salatsiliivi keele parim tundja toob selle väite tõestuseks oma kirjutises tabeleid ja protsendiarvutusi, milles kõik numbrid on kindlasti õiged, kuid järeldused ei kajasta sellest hoolimata läti verbiprefiksite omaksvõetuse tegelikku taset. Winkler loendab Sjögreni materjalikogu 2181 lauses 391 verbiprefiksite esinemisjuhtu (kõik läti prefiksid on esindatud) ja saab prefiksiga lausete osakaaluks 17,9\%. 
See statistika ei võta arvesse, kui palju on 2181 lause hulgas selliseid, milles semantiliselt pole aspekti väljendamise võimalustki - prefiksi kasutamiseks puudub motivatsioon (nt lk 162-163: Meie tüdrukute hulgas on ka ilusaid. Paljud ei ole ilusad. See raamat kuulub minule. See on minu raamat jt). Kui prefikseid loendada ainult sellistes lausetes, kus esineb aspektivõimega verb või verbaalnoomen, siis kasvaks läti keele prefiksitega lausete osakaal võibolla mitu korda (vt ka Hint 2018).

Verbiprefiksite kasutamist Kuramaa liivi keeles on kirjeldanud Fanny de Sivers oma väikeses monograafias "Die lettische Präfixe des livischen Verbs" (Nancy: Impremerie Berger-Levrault, 1971). Ka Kuramaa liivi keel on üle võtnud kõik läti keele 11 verbiprefiksit, nad asendavad või täiendavad perfektiivsusadverbe, mis on olnud algsemad perfektiivsuse väljendajad. Fanny de Siversi hinnangus rikastavad läti verbiprefiksid liivi keelt, aga samas pole nad vältimatud (lk 80-81). Tõepoolest, “Ūž Testament. Evangeliumõd ja Aposteld Tȳöd" (Helsinki, 1937) väldib läti prefikseid - ka Sjögreni materjalis esindatud Uue Testamendi katkendid (mäejutlus ja Meie Isa, mõistujutt kadunud lambast jt) saavad Kārli Stalte, Lauri Kettuneni jt liivi keele entusiastide tõlketöös hakkama lätipärasusi püüdlikult vältides. Aga see on sihipärase taotluse tulemus, mitte rahvakeele kajastus.

\section{Tänapäine probleem on aspekti väljendamise ähmastumine}

Käesolevas artiklis käsitletav probleem on täisobjekti juhtude vähenemine ja aspektilisuse ähmastumine eesti keele suulises ja kirjalikus kasutuses otse tänapäeval. Täisobjekti reegleid lihtsalt ei järgita enam ja see tendents kasvatab ennast ise: osaobjekti kasutamise juhud üldistuvad seda kiiremini, mida sagedamini osaobjekti kasutatakse täisobjekti asemel (laviini põhimõte). Kui juba objektireeglite järgimise olukorras täisobjekti juhud moodustavad/moodustasid napi kolmandiku kõigist objekti juhtudest (Tauli 1981: 79; ka Eslon \& Õim 2010), siis osaobjekti reeglivastane eelistamine kasvatab statistilist mõju keelekasutusele: vähegi ebamäärastes olukordades valitakse automaatselt osaobjekt ja nii see läheb, kuni osaobjekt kehtestab end enesestmõistetavusena ka territooriumil, mis seni kehtinud reeglite järgi ühemõtteliselt kuulus täisobjektile.

Partitiiv on eesti keele morfoloogias kõige keerulisemate moodustamisreeglitega kääne; ka süntaksis on partitiivi kasutamine reglementeeritud (või kirjeldatud) keeruliste reeglitega, mida on põhjust pidada eesti keele grammatiliste kategooriate väljendamisel (või grammatiliste vormide semantilisel tõlgendami- 
sel) väga olulisteks. Oleks ootuspärane, et eesti keele grammatikas toimuvate nihete puhul partitiivi kasutamist pigem välditakse. Paradoksaalsel kombel nii nähtavasti ei lähe. Morfoloogias on küll mõne sõnatüübi mitmuse partitiiv lihtsustumas aglutinatiivseks (endise-i-d,aktuse-i-d), aga lausesüntaksis tuleb nentida partitiivi lisanduvat kasutamist, mitte selle vältimist.

1999. aasta juunis Tallinnas peetud IV Välis-Eesti kongressile saadetud ettekandes nentis Ohio Ülikooli kauaaegne professor, Tartu Ülikooli audoktor Ilse Lehiste muu hulgas järgmist:

Eesti keele oskuse taseme hindamisel on diagnostiline näiteks sihitise käänete kasutamine. Kirjalik test väliseestlaste erinevatesse põlvkondadesse kuulunud 97 isikule näitas, et vanem generatsioon eksis täis-ja osasihitise käänete valikul harva, 1941-1960 sündinud näisid tajuvat vahet täis-ja osasihitise vahel, kuid eksisid sihitise käändevormide valikul, nendest noorem põlvkond ei osanud täis- ja osasihitise vahel enam vahet teha.

Selline nivelleerumine toimub põlvkondade vahetudes kõigi väljarändajate keeles ning on huvitav, et ka Ameerika soomlaste sihitise kasutamine on lamendunud samal kombel.

Kodueesti keelt on sel sajandil eriti tugevasti mõjustanud vene keel, nii et eesti keeles on hakatud matkima vene keele mitme morfoloogilise ja süntaktilise konstruktsiooni sisestruktuuri. (Lehiste 1999)

Tollest kongressist möödunud 20 aastaga (vähem kui üks inimpõlv) on eesti keele kasutamisel üheks morfosüntaktiliseks nihkeks partitiivi aina lisanduv esinemine konstruktsioonides, milles partitiiv on reeglivastane.

Ilse Lehiste nending viitab halvemal juhul ebastabiilsusele eesti keele identiteedi väga olulistes ja kõige omapärasemates kihistustes, paremal juhul grammatika ümberstruktureerumisele. Kõige silmatorkavam muutus on osaobjekti ülekasutamine täisobjekti arvel, mida võib tõlgendada kui partitiivi üldistumist akusatiiviks. See toob vältimatult kaasa muutusi aspekti väljendamisel või väljendamata jätmisel: uuskasutusviiside käändevorm ei ole enam seotud tegevuse resultatiivsusega ning ka jaatava ja eitava lause objekti reeglid ei toimi enam varasema järjekindlusega. Paradigma muutus algab aspekti (perfektiivsuse-resultatiivsuse $v s$. imperfektiivsuse-lõpetamatuse) väljendamata jätmisest või väljendamise muutusest (perfektiivsusadverbide abil), kuid partitiivi kasutamine lisandub ka väljaspool objekti valdkonda, põhjustades muutusi kongruentsis ja rektsioonis ning subjekti tõlgendamises; isegi mineviku liitaegade kasutamise vähenemine võib olla seotud aspekti problemaatikaga.

Kõige üllatavam on, et partitiivi tugev ülekasutamine varasemaga võrreldes on kaasa tõmbamas ka osa vanemast põlvkonnast, kelle varasemates keeleharjumustes seda nähtust sellisel kujul on raske oletada. 
Partitiivi laienemise põhjusteks võib oletada mitme objektireeglitele ebasoodsa asjaolu kumuleerumist:

- partitiivse osaobjekti statistiline ülekaal (2/3 sihitise juhtudest ka reeglite järgimise korral (Tauli 1981);

- mõne suure käändtüübi objektikäänete grammatiline homonüümia (pesa : pesa : pesa 'nom, gen, part'; mõnes laadivahelduslikus käändtüübis on objektikäänetest nominatiiv ja partitiiv homonüümsed: õde : õe : ode); mitu objektikäänet on homonüümsed maa-tüüpi sõnades;

- indoeuroopa keelte (tänapäeval vene ja inglise, kuni 20. sajandi alguseni saksa ja vene keele) erodeeriv mõju aspekti väljendamisele objekti käändevormiga;

- Eesti mitte-eestlaste eesti keeles valitsev lihtsustatud partitiivne-akusatiivne objekt (integratsioon!);

- väliseestlaste kolmandas põlvkonnas valitsev partitiivne objekt, aspektile tähelepanu pööramata (saksa, rootsi jt keelte mõjud).

Eesti keelehoole ei taha probleemi märgata, kirjastuste ja meediaväljaannete keeletoimetajad suhtuvad eesti keele süntaksi põhimõttelisse teisenemisse erinevalt. Üldiselt vaadatakse mööda tegelikust keelekasutusest, kus osa- ja täisobjekti kasutamise reeglid järjekindlalt enam ei toimi, kuigi mõned keeletoimetajad ilmselt püüavad traditsiooni hoida. Kui tõele silma vaadata, siis tuleks tunnistada, et tavaelu keelekasutuse ja eesti kõrgkirjakeele osa- ja täisobjekti kasutamine on lahknemas ning tegeliku keelekasutuse süntaksis seisab ees ülioluliste reeglite ümbersõnastamine. See võib tähendada süntaksi terminoloogia ja liigituste paradigmaatilist muutust. Eestlased hakkavad tasapisi oma kodumaal Eestis eesti keelt kõnelema sellise grammatikaga, nagu oleksid nad siin kolmanda põlve pagulased võõral maal.

\section{Uuenduslik partitiiv}

\section{Aspekt: sisulise resultatiivsuse väljendamine partitiivse objektiga genitiivi ja nominatiivi asemel}

EKG II § 506, lk 49 ütleb: “Objektivariandi valik oleneb kõigepealt verbi aspektist ..” Enam ei ole see nii selge. Lõpetatust või resultatiivsust on hakatud väljendama senise grammatika seisukohalt vastuoluliselt: välja ehitama ja välja nõudma on resultatiivse tähendusega ühendverbid (ehitas selle välja ja ehita see välja vs. ehita seda, kuni jaksad; nõudis selle välja ja nõua see välja vs. nõua 
seda). Partitiivi kasutamine resultatiivse tegevuse puhul on normgrammatika ja varasema keeleinstinkti seisukohalt viga või uuendus.

\section{A. Spontaanne partitivive objekt}

Järgnevad näited on viimistletud tekstina kirja pannud vanema põlvkonna professor, kes on väga nobeda sulega puhtalt eesti taustaga kirjutaja; näited on laiemale ringile saadetud meilikirjadest (niisiis ei saa mängus olla keeletoimetaja käsi).

\section{$\underline{\text { Isikuline tegumood }}$}

"Õnneks toob P. H. oma .. artiklis sõnaselgelt välja vajaduse välja ehitada Tartu kaudu Riiga $k$ u l g e v a t ra ud t e ed (pro kulgev raudtee 'nom')." "Tuleb kasvõi Euroopa Kohtu vahendusel välja nõuda s e l g i t u st (pro selgitus 'nom'), miks .."

“.. ma ristisin te da (pro tema 'gen') Pärnu ministriks"; ristima on kasutatud nimetama tähenduses, kuid nende verbide tähendus erineb just perfektiivsuse poolest

“.. võiks .. majanduskomisjoni $R B$ - te e m a list is t u n git (proRB-teemaline istung RB-teemalise istungi 'nom gen') korraldada laupäeval .."

\section{$\underline{\text { Umbisikuline tegumood }}$}

"Praegu tagatakse vaid seitsmendikku (pro seitsmendik 'nom') rahast."

"Ja millist valikut (pro milline valik) tehakse?"

Nendes lausetes on täidetud nominatiivse või genitiivse täisobjekti kasutamise semantilised tingimused, partitiivi kasutamine on üldistus, mis aspektiga ei arvesta - aspekti ei püütagi väljendada (resp. ei püüta väljendada objekti käändevormi abil).

\section{B. Täisobjekti nominativi asemel partitiiv}

Kõik näited on tõestatavalt trükistest ja raadioeetrist.

Isikuline tegumood

"Kui Rail Balticu e hitust (pro ehitus 'nom') onnestub nurjata, arvan teadvat, kes ja kus .." 
“.. paljudelt huultelt kostab k ü s i mu st (pro küsimus 'nom'), kas me ..”

“.. ning otsisid lahendust, kuidas saada Eestile $u$ ut pare mat preside nti (pro uus parem president 'nom')."

“.. sa ei öelnudki mulle, milli st lind u (pro milline lind 'nom') kella sisse panna."

“.. on tegevjuht võtnud enda südameasjaks muuta te $r$ v e $t$ Ida-Virumaa su u ri mat li nna (pro terve suurim linn 'nom') ja eelkõige selle $k$ e $s$ kust (pro keskus 'nom') elamiseks .. paremaks kohaks."

“.. Maaülikooli .. tuuakse söödaproove, et teha kindlaks sööda to ite $v \ddot{a} \ddot{a} r t$ s st ja $k v$ a li te e t $i$ " (tuleks eelistada nominatiivi, sest kindlaks tegema on perfektiivse tähendusega verb; kui oleks, et uurida, siis küll partitiiv).

“.. s e da ka te $t$ (pro see kate) tuleb leida, praegu seda katet pole." (Jutt on riigieelarvest.)

"Millegipärast tunnistab kohus ohtlikuks ainult neid patsiente (pro need patsiendid 'pl nom'), kes on kasutanud füüsilist vägivalda."

“.. keeld .. korraldada .. õppeaasta a va a kt ust (pro avaaktus 'nom') ..”; on võimalik, et sellises lauses läheb semantiline eitus (keeld) segamini grammatilise eitusega, mis eeldab partitiivset objekti.

\section{Umbisikuline tegumood}

Gümnaasiumiõpiku reegel ütleb: "Ainsuslik täissihitis on nimetavas, kui öeldis on umbisikulises tegumoes” (Vääri 1978: 119), ent seegi muutub:

“.. sellist pakkumist (pro selline pakkumine) tehakse vaid kord elus ..";

"E si e te nd ust (pro esietendus) planeeriti detsembrisse .."

“.. tavaliselt tuuakse tervisliku toitumise etaloniks Vahemere $p$ i i r $k$ o $n d a$ (pro piirkond 'nom')."

"Kõik see toimus üritusel, mi da peeti (pro mis peeti) Viinis 21. kuni 23. oktoobrini."

"1958. aastal ilmunud r a a m a tut (pro raamat "nom') "Modigliani" on tôlgitud mitmesse keelde."

Välismaise taustaga keskmise põlve eesti keeleteadlane kasutab keeleteaduslikus artiklis niisugust objekti: ".. millega tunnistati ametlikult eesti vi i pe k e elt (pro viipekeel 'nom') iseseisvaks keeleks."

2008. aastal andis kirjastus Sinisukk välja tõlgitud kunstiraamatu "100 kauneimat naist maalikunstis" (tõlkinud Maaja Liidja, toimetanud Monica Tõnismann). Selles raamatus leiab lauseid, mis eksivad umbisikulise öeldisega lause objektireegli vastu: "Gabrielle ja Julienne d'Estrées'd $k$ u j u t a v a t m a a li 
(pro kujutav maal) omistatakse Fontainebleau koolkonnale”; “.. Gabrielle’i heleblond juuksevärv oli tollal väga moodne ja s e da (pro see) saavutati tihti kunstlikult, abivahenditega" (lk 32-33).

Jaatava lause objektivigu leiab ridamisi: "Et Cezanne te d a (pro tema) rehabiliteeris, on loogiline ..” (lk 166); “.. tema ja Tristan pidasid kahevõitluse, et otsustada lahingu s a a t u st .." (pro saatus; lk 156); "Seda lühikest hispaanlast, kes .. algatas kõ $i k i$ (pro kõik) oma eluaja peamisi avangardistlikke kunstistiile .. (pro peamised avangardistlikud kunstistiilid ..)" (lk 50).

Mida rohkem ilmub lohakalt toimetatud tekste, seda kergem on mõtelda, et norm ongi kõikuv. See avab tee lauseehituse muutustele, millest võib mööda vaadata nagu algava haiguse sümptomite puhul tavaline. Nad võivadki olla ebaolulised, aga võivad ka olla algava maalihke ennustajateks. Näide mineviku liitaja kaotsimineku kohta samast raamatust: "Itaalia, mis polnud pikka aega rahvuslik ega riiklik tervik, vaid hulk omaette linnriike ja väikeriike, $m$ i $d a$ geograafia juhuslikult kõrvuti p a n $i$..” (lk 124). Veel mõni aeg tagasi - reeglite kehtimise korral - oleks selle lauseosa lõpp olnud teistsugune: " $m$ i l le geograafia o $l i$ juhuslikult kõrvuti p a n $n$ u d."

\section{Täisobjekti genitiivi asemel partitiiv}

Kõik näited trükistest, k.a ilukirjandusest. Järgnevate näidete puhul tuleb arvestada, et teksti võib olla aktsepteerinud ka väljaande keeletoimetaja.

“Ta (Christa Wolf) ei tahtnud, et Saksa Liitvabariik hõivaks $S D V-d$ (pro $S D V$ 'gen')."

"Russofoobia on kindla ühiskondliku kihi ideoloogia, see kiht moodustab $v \ddot{a}$ he must (pro vähemuse 'gen')."

"..presidendivalimist (pro presidendivalimise 'gen') võitis .."

“.. ükskõik, millist ebas õbralikku sammu (pro millise ebasõbraliku sammu 'gen') Venemaa ka ei astuks, saab selle kohe .."

“.. olid ületanud piirijo o nt (pro piirijoone 'gen'; kui oleks: “olid ületanud piirijoont mitu korda ..", siis küll)".

"Lõpuks ületas see arv miljo nit (pro miljoni 'gen'; jutt on pagulastest Saksamaal)."

"Sellest saab su ure mat rahuldust (pro suurema rahulduse) kui kingitusest .."

“.. ta avaldas .. talle kapos töötamise ajast teada olnud $r$ i i g i s a l a d u st (pro riigisaladuse 'gen').”

“"Faatum” .. sisaldab EW riigikontrolöri Karl Soonpää pä evikut .. (pro päeviku 'gen')." 
"See põhjustabs u urt lang ust (pro suure languse 'gen') majaelanike elukvaliteedis .."

“.. kirjastaja küsis s u urt su m mat (pro suure summa 'gen') selle eest, et laulud lisataks laste lauluõpikusse."

"Te d a (pro tema 'gen') pä̈̈stis Gamba-nimeline šerpa .."

Kogenudki kirjutaja (elukutseline tippajakirjanik) võib vormilise osaobjektiga väljendada sisulist täisobjekti: pealkirjas võib olla "Peaminister vôtab naise", aga tekstis "N a $i$ st oleks saanud võtta palju varem .." *Peaminister võtab naist pole lausena aktsepteeritav, küll aga Naise oleks saanud võtta palju varem .. Pealkirja ja tekstilause sisu ei erine aspekti seisukohalt. Kui objekti vorm on kahel juhul erinev, siis saab järeldada, et kirjutajal ei ole resultatiivsuse järjekindel vormiline väljendamine tähtis, ta ei taju, et osaobjekti kääne ei väljenda resultatiivsust.

Muutuvad ka traditsioonilised sõnaühendid: “.. teeb sellist $n \ddot{a} g u$, et kui ei vaata, siis seda ei ole" (vrd Õim 1993: $285 \mathrm{jj}$... teeb ainult s e ll $i$ s e $n$ ä o 'gen'; tegi nä o, nagu poleks .. jt; ÕS 1999 ja ÕS 2013 märksõna nägu: Teeb $n \ddot{a ̈}$ o, nagu ei kuuleks jt). Lisanäiteid leiab ka tunnustatud kirjanike teostest. Ei märgata sedagi, et keeletoimetajatele kohustuslikud preskriptiivsed sõnaraamatud neid muutusi ei tunnusta.

Järgnevad näited on pärit väliseestlase Käbi Laretei tekstist raamatus "Okas ja Käbi” (Okas \& Laretei 2012). Teksti on toimetanud kodu-Eesti kirjainimesed Sirje Endre ja Anu Saluäär; sellest hoolimata kinnitavad need näited Ilse Lehiste diagnoosi:

“.. imelikul kombel tulevad mul .. meelde sündmused, mi $d a$ (pro mille) ammu olen unustanud" (lk 27); võimalik oleks mida olen pü̈̈dnud unustada.

"Kui ma .. hüüdsin: "Peata!", ütles ta s e d a (pro selle) edasi sohvrile .." (lk 31)

"Hindemith kirjutas prelüüdide asemel interluudiumeid ja kui $v$ i $i$ m a s le he külge (pro viimane lehekülg) ümber keerata, moodustab see esimese prelüüdi alguse" (lk 64)

Mõningase võõrtaustaga eesti luuletaja kirjutab nii: "Eestis sündinud lapsed saavad eesti k e elt (pro eesti keele) oma vanemate käest nagu king it ust (pro kingituse), vaeva nägemata." 


\section{Kvantorfraasi põhisõna ja täiendi ümbertõlgendamine}

\section{kongrueeruvaks konstruktsiooniks}

Mati Erelti peatoimetamisel ilmunud EKG II § 510, lk 53 sõnastab reegli: "Põhiarvsõnad alates kahest, murdarvsõna poolteist, ligikaudset hulka märkivad sõnad paar, paarsada, kümmekond, sadakond ja mitu on täissihitise peasõnana nimetavas, murdarvsõnad veerand, kolmveerand ja pool aga kas nimetavas või omastavas, kui neid laiendab partitiivne täiend. Asesõna kõik on täissihitisena alati nimetavas." (Vt ka Aavik 1936 § 378a: See teos sisaldab k o $i k$ tarvilised a nd me d.) EKG II näites Tegin täna $k$ a $k s$ h e a te $g u$, kus heategu on partitiivis, pole aga see grammatilise homonüümia tõttu eriti nähtav. Selle paragrahvi vastu eksib nähtavasti ka $§ 595$ (lk 140), kus kvantorfraasi käsitluses leidub näitelause Sul on vaja viit rubla, aga mul on ainult viis kopikat (rubla on partitiivis). Just see ekslik näide on praegu muutumas normiks: Salatisse lisamiseks on vaja k olme to ma tit (reeglikohane: kolm tomatit), vt tabel 1.

Tabel 1. Traditsiooniline vs. uuenduslik objektikäände kasutus.

\begin{tabular}{|c|c|}
\hline $\begin{array}{l}\text { Traditsiooniline: } \\
\text { nominatiiv + partitiiv }\end{array}$ & $\begin{array}{l}\text { Uuenduslik: } \\
\text { arv- ja mõõdusõna kongrueerub }\end{array}$ \\
\hline $\begin{array}{l}\text { Arvsõnaline põhisõna partitiivse } \\
\text { täiendi ees jääb nominatiivi, selle } \\
\text { kasutamine on lihtne; } \ddot{u} k s \text { on } \\
\text { erandlik. }\end{array}$ & $\begin{array}{l}\text { Põhisõna ja täiend on vahetanud } \\
\text { kohad; kongrueeruv konstruktsioon } \\
\text { on liitarvsõnade puhul keeruline, } \\
\text { väljarääkimine kohmakas. }\end{array}$ \\
\hline Valik sisaldab ühe mündi. & Valik sisaldab ühte münti. \\
\hline Valik sisaldab kaks münti. & Valik sisaldab ka hte münti. \\
\hline $\begin{array}{l}\text { Valik sisaldabkolmsada } \\
\text { seitsekümmend kuus münti. }\end{array}$ & $\begin{array}{l}\text { Valik sisaldabkolmesadat } \\
\text { seitsetkümmend kuut münti. }\end{array}$ \\
\hline $\begin{array}{l}\text { Valik sisaldab kõ ik kehtivad } \\
\text { mündid. }\end{array}$ & $\begin{array}{l}\text { Valik sisaldabkõiki kehtivaid } \\
\text { münte. }\end{array}$ \\
\hline $\begin{array}{l}\text { EAS tegi Ilvese nimel k } \tilde{i} i k \\
\text { (võimaliku). }\end{array}$ & $\begin{array}{l}\text { EAS tegi Ilvese nimel kõ } i k e \\
\text { (võimalikku). }\end{array}$ \\
\hline $\begin{array}{l}\text { Tee parandamiseks oli vaja k o or e } m \\
\text { kruusa. }\end{array}$ & $\begin{array}{l}\text { Tee parandamiseks oli vaja } \\
\text { k o or m a t kruusa. }\end{array}$ \\
\hline Pidin p a ar luuletust esitama. & Pidin p a a ri luuletust esitama. \\
\hline
\end{tabular}

Peasõna ja täiendi formaalne tõlgendus on keelekasutaja grammatikas muutumas: sihitisena tajutakse münti ja selle arv- või mõõdusõnaline kvantifikaator kongrueeritakse põhisõnaga. Selliseid näiteid on ajakirjanduses ja raadios väga sageli (korralikult keeletoimetatud kirjanduses harvemini) ning nad on selgelt 
vastuolus traditsioonilise keelekasutusega. Partitiiv on objekti käändena üldistumas ning täis- ja osasihitise eristamine ähmastub. Kodueestlaste keelekasutus on selle eristuse osas nivelleerumas kolmanda põlve väliseestlastega ja kodumaiste mitte-eestlastest lõimunutega samale tasemele.

Lisanäiteid ajakirjandusest ja kirjandusest, ka kvaliteetajakirjandusest, nagu National Geographic Eesti ja suured päevalehed (siin tuleb niisiis arvestada keeletoimetamisega).

“.. kandnud hellalt hoolt fotokogu eest, mis sisaldab umbes $k$ a he $k$ s a $t$ miljonit fotot (prokaheksa 'nom')."

"Taskila ajal miljo nit reisijat (pro miljon 'nom') aastas vedada jõudnud lennufirma .."

“.. kelle sissetulek ületab viitkümmend tuhandet eurot (pro viiskümmend tuhat 'nom')."

“.. võlg ületab kolmesada tuhandet krooni (pro kolmsada tuhat 'nom')."

“.. endise abilinnapea vastu on esitatud kaks nõuet, mis kokku ületavad kolme miljonit krooni (prokolm 'nom')."

"Raamat koondab Postimehe lisas AK ilmunud sadat lu uletust (pro sada 'nom')."

"Keskerakond võiks endale vôtta valitsuses s e it s et mi nis triko hta .. (pro seitse 'nom')."

"Oli vaja veel sadat tuhandet kroo ni (pro sada tuhat 'nom')."

".. sõjavägi aitas evakueerida neljakümmend tuhandet inimest (pro nelikümmend tuhat 'nom')."

"Programm hõlmab viitkümmend üritust (pro viiskümmend 'nom')."

“.. tuleb muudatused ära teha, ootamata $k$ ü m met a a stat (pro kümme 'nom')."

“.. isikuomadusi, mis panid Darwini veetma ka ht $k \ddot{u ̈ m}$ mend a a stat (pro kakskümmend 'nom') "Liikide tekkimist" täiendades .."

".. tegemist on vaid esimese köitega pikemast ettevõtmisest, mis peaks sisaldama veel vähemaltküm met ra a ma tuköidet (prokümme)." "Selle asemel, et esimesel võimalusel lasta maha kõ $i k i$ ISIS-e terroriste (pro kõik ISIS-e terroristid 'pl nom') .."

Mõistagi on nendest lausetest võimalikud variandid, milles ühilduv arvsõna on ainuvõimalik: "Sõjavägi aitas evakueerimisel neljakümmend tuhandet inimest." Selles vahe ongi, et siin ei väljenda lause resultatiivsust või tegevuse lõpetatust, vaid nendib protsessi. Paar välis-Eesti keelenäidet satub ka sellesse alajaotusse (Okas \& Laretei 2012): “.. ta on teretulnud, et t a s s i ('part') ko h vi ('part' pro 
tass 'nom' kohvi 'part') juua" (lk 83). "Pidin pa ari ('part') pa la ('part' pro paar 'nom' pala 'part') mängima, samal ajal kui publik oli sunnitud saali uste taga ootama" (lk 103).

Need näidete tüübid on juba muutumas kasutusnormiks või kasutusnormi variandiks kõigis keelekasutuse valdkondades nii suulises kui ka kirjalikus väljenduses: väga sageli Rahvusringhäälingu saatejuhtide ja diktorite tekstides ja ajalehtedes, harvemini kõrgkvaliteetsetes kultuuriajakirjades ja ilukirjanduses (tõlkekirjandus kaasa arvatud). Viimastel puhkudel tuleb küsida, kas keeletoimetajad korrigeerivad sellist kasutust, kas nad on need muutused aktsepteerinud, lepivad nendega või on ise koguni nende juurutajad?

Tõlketeoste objektikasutuse jälgimine ei anna ühemõtteliselt selgeid vihjeid lähtekeele võimalike mõjude kohta ega isegi põlvkondade objektikasutuse erisuste kohta. Näiteks 1981. aastal ilmunud inglise keelest tõlgitud David Weissi "Alasti tulin ma. Romaan Auguste Rodinist" (tõlkinud Eha Vasara, toimetanud Johannes Seilenthal; kirjastus Kunst) on erakordselt halva eesti keelega, nii et ka päris võimatud objektikasutuse juhud paigutuvad tõlkija ja toimetaja üldise keelehoolimatuse konteksti (nt lk 150: "Kunagi ei tea ette, kas modellil on hea figuur, enne kui ta pole endal riided seljast ära võtnud"; lk 217: "Ja ka praegu ma ei saa silmad sulgeda .."; selliseid näiteid on väga palju).

Seevastu 34 aastat hiljem, 2015. aastal ilmunud Michel Houellebecqi "Saare võimalikkus" (prantsuse keelest Triinu Tamm, toimetanud Janne Kukk, korrektuuri lugenud Hille Lagerspetz; Varrak) on laitmatus eesti keeles - rohkem kui 350 leheküljel märkab ehk paari juhtu, kus oleks võinud kaaluda aspekti selgemat väljendamist, nt “.. ütlesin paar banaalsust, mida nad aupaklikult kuulasid” (lk 204; või ehk: “mille nad aupaklikult ära kuulasid”).

\section{Mida teha?}

Hoolimatust või mõistmatust aspekti väljendamisel on olnud kõigil aegadel, aga kõige uuemal ajal näib see selge tendentsina suunduvat Ahrensi poolt sedastatud normi ähmastumisse - kus vähegi tundub võimalik olevat nii täiskui ka osaobjekt, seal valitakse partitiiv. Sellise kõikuvuse olukorras tuleb ette ka täisobjekti kasutamist osaobjekti asemel (“.. püüdis leida vastuse küsimusele ..”), aga selliseid juhte on väga harva. Ka käesolevas kirjutises võib olla mõnigi vaieldav näide, kuid üldtendentsis ei saa olla kahtlust.

Tähelepanu juhtimine sellistele muutustele on raske, sest n-ö tavaline keeleavalikkus märkab keelemuutusi laensõnade tasandil ning üksikute morfoloogiliste vormide normimuutusi, mitte muutusi konstruktsioonides, mis on keele grammatika tõeline identiteet. 
Küsimuste küsimuseks jääb klassikaline Mida teha? Keeleteadlased teavad, et keele muutumist tagasi hoida ei ole võimalik, parimal juhul on muutusi võimalik mingis ulatuses suunata. Mingil hetkel muutub ka koordineeritud võitlus muutuse pidurdamiseks ressursi raiskamiseks. Praegu on raske märgata, et probleem oleks akuutsena üldse teadvustatud. Eesti kõrgkeele traditsioonidele mõjub kõige laastavamalt Rahvusringhäälingu populaarsete programmide saatejuhtide nõrk keeleline enesekontroll (õieti selle puudumine).

Väliseestlaste kolmandas-neljandas põlvkonnas märgatav objektireeglite lõdvenemine ei ole kellegi süü, see lihtsalt on nii. Sama tuleks nentida Eesti mitte-eestlaste objektikasutuse kohta. Kui eestlaste ühiskond soovib, et Eesti mitte-eestlased üha rohkem kasutaksid kõnes ja kirjas eesti keelt, siis tuleb võtta teadmiseks, et see võib eesti keele identiteedile maksta tõsiseid kaotusi. Aga võibolla tagasiteed enam polegi?

Küsimuseks jääb ka suhtumine traditsiooniliste reeglite järgi kirjutatud või redigeeritud klassikasse. Kas klassikute keelt tuleb hakata parandamauusredigeerima? Vähemalt praegu oleks selline algatus küll enneaegne. Kurb, et aspekti-objekti väljendamise muutustest tuli kõnelda Kuusalus Eduard Ahrensile püstitatud ausamba avamisel 9. augustil 2017.

Et perfektiivse-resultatiivse aspekti väljendamine vajab üha suuremal määral perfektiivsusadverbide tuge, see on juba tõsiasi: Tegi selle ära. Tegi selle valmis. Vaatas selle üle. Vaatas selle järele. Kuid mõtelda tuleks ka selle üle, kas eesti keele süntaksiteooria juba kinnistunud paradigmad, terminoloogia ja reeglistik on edaspidigi senisel kujul adekvaatsed. Peale perfektiivsuse-resultatiivsuse väljendamise muutuste võib olla põhjust laiemakski revisjoniks-auditiks, mis hõlmaks eksistentsiaallause, kvantorfraasi, kongruentsi, transitiivsuse ja rektsioonid, grammatilise ja semantilise eituse, liitaegade kasutamise, tuleviku väljendamise, käänete funktsioonid ... See, kuidas keeleteadlased neid liigitusi ja mõisteid kasutavad või mis keerulisi nimetusi neile antakse, huvitab praktilist keelekasutajat vähe. Keelekasutaja teeb oma laused kindlate mallide järgi ja kui need mallid hakkavad muutuma, siis grammatika muutub (vt tabel 2).

Tabel 2. Traditsiooniliste lausemallide muutumine.

\begin{tabular}{|l|l|}
\hline Traditsioonilised mallid & Segamini mallid \\
\hline $\begin{array}{l}\text { Seda raamatut on tôlgitud palju. } \\
\text { “Modigliani” on tôlgitud mitmesse } \\
\text { keelde. }\end{array}$ & $\begin{array}{l}\text { Raamatut "Modigliani” on tõlgitud } \\
\text { mitmesse keelde. }\end{array}$ \\
\hline Ressurssi jätkub mitmeks tarbeks. & Ressurssi jääb napiks. \\
\hline Ressurss jääb napiks. & \\
\hline
\end{tabular}


Eesti keele grammatika on praegu üsna labiilne: võib toimuda paradigmamuutus, mis võib jätta eilsed vaieldamatud tõed katteta esijoones süntaksis ja sõnamoodustuses. Selle tunnustamiseni võib minna aega ning kõige parem oleks, kui praegune ebakindlus ja mõningane segadus taanduks traditsioonilisse reeglistikku. Aga kui seda (tõenäoselt) ei juhtu, siis tuleb muutunud olukorrale silma vaadata.

\section{Kommentaarid}

1 Katre Õimu mälestuskonverentsil "Keel on teekond" Tallinna Ülikoolis 17. veebruaril 2017 peetud ettekande "Partitiivi laienemine - objekt ja subjekt, kongruents ja rektsioon" (Hint 2017) laiendatud ja edasiarendatud tekst.

2 Raili Pooli (2007) viite võlgneb autor retsensendile.

\section{Kirjandus}

Aavik, Johannes 1936. Eesti õigekeelsuse õpik ja grammatika. Tartu: Noor-Eesti Kirjastus.

Ahrens, Eduard 1853 (2003). Grammatik der Ehstnischen Sprache Revalschen Dialektes. Ross, Kristiina (koost ja toim). Uue ajastu misjonilingvist. Eduard Ahrens 200. Tallinn: Eesti Keele Sihtasutus, lk 75-429.

EKG II = Erelt, Mati \& Kasik, Reet \& Metslang, Helle \& Rajandi, Henno \& Ross, Kristiina \& Saari, Henn \& Tael, Kaja \& Vare, Silvi 1993. Eesti keele grammatika. II. Süntaks. Lisa: kiri. Trükki toimetanud Erelt, Mati (peatoimetajana) \& Erelt, Tiiu \& Saari, Henn \& Viks, Ülle. Tallinn: Eesti Teaduste Akadeemia Eesti Keele Instituut.

Erelt, Mati 2013. Eesti keele lauseõpetus. Sissejuhatus. Öeldis. Tartu Ülikooli eesti keele osakonna preprindid 4. Tartu.

Erelt, Mati \& Metslang, Helle (toim) 2017. Eesti keele süntaks. Eesti keele varamu III. Tartu: Tartu Ülikooli kirjastus.

Eslon, Pille \& Õim, Katre 2010. Objektikäänete kasutamisest sageduse ja markeerituse seisukohalt. Tragel, Ilona (toim). Keele rajad. Pühendusteos Helle Metslangi 60. sünnipäevaks / Paths of Language. Festschrift for Professor Helle Metslang on the occasion of her 60th birthday. ESUKA - JEFUL: Eesti ja soome-ugri keeleteaduse ajakiri / Journal of Estonian and Finno-Ugric Linguistics 1 (2), lk 241-261.

Hint, Mati 2017. Partitiivi laienemine - objekt ja subjekt, kongruents ja rektsioon. Keel on teekond. Diakroonilise ja sünkroonilise keelekäsitluse piirimail. Katre Õimu mälestusele pühendatud konverents 17. veebruaril 2017 Tallinna Ülikoolis. Tartu: EKM Teaduskirjastus, lk 9-13. 
Hint, Mati 2018. Salatsiliivi keele õppetunnid. J. A. Sjögreni salatsiliivi materjalide uusilmumine. Avaldamisel Akadeemias.

Kont, Karl 1963. Käändsõnaline objekt läänemeresoome keeltes. Eesti NSV Teaduste Akadeemia Keele ja Kirjanduse Instituudi uurimused IX. Tallinn: Eesti Riiklik Kirjastus.

Lehiste, Ilse 1999. Keel ja identiteet. Utno, Leili (koost). IV Välis-Eesti kongress 29.30. juunil 1999. a. Tallinnas. Ettekannete kokkuvõtted. Tallinn: Välis-Eesti Ühing, lk 5.

Metslang, Helle 2001. On the development of the Estonian aspect: The verbal particle ära. Dahl, Östen \& Koptjevskaja-Tamm, Maria (toim). The Circum-Baltic Languages. Typology and Contact. Vol 2: Grammar and Typology. Studies in Language Companion Series 55. Amsterdam \& Philadelphia: John Benjamins Publishing Company, lk 443-479.

Norvik, Miina \& Piiroja, Piret 2013. Aeg ja aspekt. Tragel, Ilona \& Veismann, Ann \& Piiroja, Piret (toim). Teoreetilisest keeleteadusest Eestis III. ESUKA - JEFUL: Eesti ja soome-ugri keeleteaduse ajakiri / Journal of Estonian and Finno-Ugric Linguistics 4 (1), lk 53-72.

Ogren, David 2017. Finiitverbi mõju objekti käändele $d a$-infinitiiviga objektikonstruktsioonis. Keel ja Kirjandus 4, lk 258-271.

Okas, Evald \& Laretei, Käbi 2012. Okas ja Käbi. Randjärv, Laine (koost) \& Endre, Sirje \& Saluäär, Anu (toim). [Tallinn]: Kirjastus SEJS.

Piibli Ramat 1739 = Piibli Ramat, se on keik se Jummala Sanna, mis Pühhad Jummala Mehhed, kes pühha Waimo läbbi juhhatud, Wanna Seädusse Ramatusse Ebrea Kele ja Ue Seädusse Ramatusse Kreka Kele essite on ülleskirjotanud, nü̈d agga hopis, Jummala armo läbbi, meie Eesti- Ma Kele Essimest korda üllespandud, ja mitme sündsa salmiga ärraselletud. Essimesses otsas on Üks öppetus ja maenitsus nende heaks, kes Jummala sanna omma hinge kassuks pü̈̈dwad luggeda. TALLINNAS, Trükkis sedda Jakob Joan Köler. 1739. Aastal. Faksiimile 1990. Tallinn: Eesti Raamat.

Pool, Raili 2007. Eesti keele teise keelena omandamise seaduspärasusi täis- ja osasihitise näitel. Dissertationes philologiae estonicae Universitatis Tartuensis 19. Tartu: Tartu Ülikooli Kirjastus (http://dspace.ut.ee/handle/10062/2237).

Rajandi, Henno \& Metslang, Helle 1979. Määramata ja määratud objekt. Eesti NSV Teaduste Akadeemia Keele ja Kirjanduse Instituut. Preprint. Tallinn: Valgus.

Ross, Kristiina 2003a. Viimane misjonilingvist Eduard Ahrens eesti kirjakeele reformijana. Keel ja Kirjandus 5, lk 321-330.

Ross, Kristiina 2003b. Eduard Ahrens 200. Oma Keel 2, lk 53-59.

de Sivers, Fanny 1971. Die lettische Präfixe des livischen Verbs. Les Préfixes du Verbe Live. Nancy: Impremerie Berger-Levrault.

Tālberga, Ilze \& Mandel, Aive 2017. On the imperfective and perfective aspect in Estonian and Latvian. Praakli, Kristiina \& Tender, Tõnu \& Lang, Valter (toim). Keele kõrgendikud. Pühendusteos professor Birute Klaas-Langi 60. sünnipäevaks. ESUKA JEFUL: Eesti ja soome-ugri keeleteaduse ajakiri / Journal of Estonian and Finno-Ugric Linguistics 8 (1), lk 241-261. 
Tamm, Anne \& Kivik, Piibi-Kai 2017. A learner's grammar for Estonian: insights from typological research. Praakli, Kristiina \& Tender, Tõnu \& Lang, Valter (toim). Keele kõrgendikud. Pühendusteos professor Birute Klaas-Langi 60. sünnipäevaks. ESUKA JEFUL: Eesti ja soome-ugri keeleteaduse ajakiri / Journal of Estonian and Finno-Ugric Linguistics 8 (1), lk 263-281.

Tauli, Valter 1981. Objektisäännön mutkistamista. Virittäjä 85 (1), lk 79-83.

Trubetzkoy 1960 = Trubeckoj, Nikolai Sergejevitch 1960. Osnowy fonologii. Moskwa: Izdatel'stvo Inostrannoj Literatury.

$\bar{U} \check{z}$ Testament $1937=\overline{U z ̌ ~ T e s t a m e n t . ~ E v a n g e l i u m o ̃ d ~ j a ~ A p o s t e l d ~ T y ̄ o ̈ d . ~ H e l s i n k i: ~}$ Suomalaisen Kirjallisuuden Seuran Kirjapainon OY, 1937.

Wiedemann, Ferdinand Johann 1875. Grammatik der Ehstnischen Sprache, zunächst wie sie in Mittelehstland gesprochen wird, mit Berücksichtigung der anderen Dialekte. St.-Pétersbourg: Imprimerie de l'Académie Impériale des sciences; faksiimiletrükk: Grammatik der Estnischen Sprache, Tallinn: Stiftung für Estnische Sprache, 2005; tõlge eesti keelde: Eesti keele grammatika. Tõlkinud Heli Laanekask. Toimetanud Ellen Niit. Tallinn: Eesti Teaduste Akadeemia Emakeele Selts, 2011.

Winkler, Eberhard 2017. Verbiprefiksid salatsiliivi keeles. Praakli, Kristiina \& Tender, Tõnu \& Lang, Valter (toim). Keele kõrgendikud. Pühendusteos professor Birute KlaasLangi 60. sünnipäevaks. ESUKA - JEFUL: Eesti ja soome-ugri keeleteaduse ajakiri / Journal of Estonian and Finno-Ugric Linguistics 8 (1), lk 349-357.

Winkler \& Pajusalu 2016 = Salis-Livisch I. J. A. Sjögrens Manuskript (ediert, glossiert und übersetzt von Eberhard Winkler und Karl Pajusalu) 2016. Hasselbatt, Cornelius \& Röhrborn, Klaus (Hrsg.). Veröffentlichungen der Societas Uralo-Altaica. Bd. 88. Wiesbaden: Harrassowitz Verlag.

Vääri, Eduard 1978. Eesti keele õpik keskkoolile. 8., parand. tr. Tallinn: Valgus. Õim, Asta 1993. Fraseoloogiasõnaraamat. Tallinn: Eesti Teaduste Akadeemia. ÕS 1999 = Erelt, Tiiu (toim) 1999. Eesti keele sõnaraamat. Tallinn: Eesti Keele Sihtasutus. ÕS 2013 = Raadik, Maire (toim) 2013. Eesti õigekeelsussõnaraamat ÕS 2013. Tallinn: Eesti Keele Sihtasutus. 
Summary

\section{Expansion of partitive case in the Estonian language into a counterpart of Indo-European accusative}

\section{Mati Hint}

Estonian linguist

10152 Tallinn, Narva mnt 25, Tallinn University

Keywords: expansion of partitive as a common case for object, expressing the aspect in Estonian, language change, the rules covering the usage of object in Estonian, typology of morphosyntax

The language-specific rules for expressing grammatical aspect in Estonian by the use of case forms of grammatical object were first described by Eduard Ahrens (1803-1863) in his "Grammatik der Ehstnischen Sprache Revalschen Dialektes" (1853). In the Estonian language the perfective aspect is expressed by the nominative and genitive cases of the object, and imperfective aspect by the partitive case of the object.

During the last 150 years since Ahrens's grammar, and later a grammar by Ferdinand Johann Wiedemann (“Grammatik der Ehstnischen Sprache ...”, 1875) the rules covering the usage of these cases for expressing aspect have been elaborated into a detailed syntactic theory.

Nowadays, however, the situation is gradually changing: under the influence of Indo-European languages the partitive case seems to occupy more and more the role of Indo-European accusative as a common case for grammatical object, leaving aside and neutralizing the expression of aspect. 